\title{
Power Factor and Your Electrical Utility Bill in Egypt
}

\author{
M. M. Abdel Aziz, Member, IEEE, E. E. Abou El-Zahab, and A. F. Zobaa, Member, IEEE
}

\begin{abstract}
Beside being a good neighbor and not causing harmonic voltage for others that are connected to your electrical distribution circuit, complying with the legal requirements of IEEE standards 519, and maintaining safe and economical operating environments for electrical equipment within your physical load, there is another very good reason to maintain a good power factor: saving money on your electrical utility bill. This letter discusses the topic.
\end{abstract}

Index Terms-Economics, harmonics, power factor.

\section{INTRODUCTION}

$\mathbf{T}$ YPICALLY, both utilities and consumers have incentives for $P F$ improvement. For a utility, $P F$ improvement reduces system losses and increases the portion of generation capacity available for productive uses. In addition, it can help maintain voltage at desired levels. Consequently, utilities often encourage consumers to maintain a high $P F$ by applying tariff clauses, which penalize consumers for low $P F$.

In Egypt, utilities impose a penalty in the form of higher charges for customers with contracted loads greater than 500 $\mathrm{kW}$ whose $P F$ is less 0.9 . From the customer's point of view, this penalty should be sufficient to motivate the installation of $P F$ correction equipment. Aside from decreasing the electric bill (or actually resulting in a bonus), other advantages of $P F$ correction include increasing internal electrical distribution system capacity, reducing distributing system losses, and enhancing voltage stability.

The following are the possible benefits that can be achieved by correcting consumer's $P F$ value.

\section{A. Elimination of the PF Penalty}

The $P F$ penalty is a multiplier applied to the normal kilowatt hour consumption charges. The penalty is based on an annual average $P F$, calculated from kilowatt hour and kVArh meters readings as follows:

$$
\text { Average annual } \mathrm{PF}=\frac{\mathrm{kWh}}{\sqrt{\mathrm{kWh}^{2}+\mathrm{kVArh}^{2}}} .
$$

When the average annual $P F$ is less than 0.9 but greater or equal to 0.7 , the penalty is calculated as follows:

$$
\text { Penalty }=(0.9-\mathrm{PF}) * \mathrm{kWh} \text { charges. }
$$

When the average annual $P F$ is less than 0.7 , the penalty is

$$
\text { Penalty }=\left[(0.9-0.7)+\frac{3}{2}(0.7-\mathrm{PF})\right] \times \mathrm{kWh} \text { charges. }
$$

\footnotetext{
Manuscript received October 2, 2002.

The authors are with the Electrical Power and Machines Department, Faculty of Engineering, Cairo University, Giza 12613, Egypt.
}

Digital Object Identifier 10.1109/TPWRD.2003.817535
If the consumer does not correct the $P F$, the penalty increases after three months to

$$
\text { Penalty }=2 *(0.9-\mathrm{PF}) * \mathrm{kWh} \text { charges. }
$$

The utility also has the right to discontinue service if the consumer does not correct the $P F$ within another six months.

\section{B. Reduction in Contract Demand}

The contract demand is the demand that the supplier of electric service agrees to have available for delivery. According to the Egyptian tariff structure, increasing the $P F$ may allow the consumer to reduce his or her contracted power. This results in the use of a different scale for calculating the cost of kilowatt hour consumption. The effect is to use smaller block sizes at higher unit energy costs and larger block sizes for the cheaper rate blocks.

\section{Bonus Due to Overcorrected PF}

According to the Egyptian tariff structure, a bonus is offered to customers when they maintain an average annual $P F$ higher than 0.92 and up to a maximum of 0.95 . This can be calculated by the following:

$$
\text { Bonus }=\frac{\mathrm{PF}-0.92}{2} * \mathrm{kWh} \text { charges. }
$$

\section{Reduction of Internal Distribution System Losses}

With active power $(\mathrm{kW})$ held constant, as $P F$ decreases, the required apparent power (kVA) increases. As a result, the electrical system resistance $\left(\mathrm{I}^{2} \mathrm{R}\right)$ losses are increased. Although these losses are small (2.5\% to $7.5 \%$ of a typical industrial load's yearly energy consumption), the effect is much more pronounced on a national scale.

\section{E. Increased Distribution System Capacity}

Low $P F$ cuts down distribution system capacity. Similar capacity improvements are possible with cables, circuit breakers, and other electrical equipment. The capacity of all this equipment to provide useful power is reduced by low $P F$. In effect, increasing $P F$ will result in increased capacity in existing electrical distribution systems. This can help offset or reduce expenses for additional system capacity.

\section{F. Enhanced Voltage Profile}

While not a reason in itself for installing $P F$ improvement equipment, better voltage stability is usually an additional benefit of $P F$ correction.

\section{PAYBACK PERIOD}

Payback period is the period of time required for the profit or other benefits from an investment to equal the cost of the invest- 
TABLE I

Simulated Results OF THE SySTEM UNDER STUdy

\begin{tabular}{c|c|c|c}
\hline Criterion & $\mathrm{PF}_{\mathrm{n}}(\%)$ & $\mathrm{P}_{\mathrm{n}}(\mathrm{kW})$ & TCOST (L.E.) \\
\hline Transmission loss & 89.47 & 4993.24 & 370866.30 \\
\hline $\begin{array}{c}\text { Transmission } \\
\text { efficiency }\end{array}$ & 89.77 & 5049.83 & 419268.20 \\
\hline $\begin{array}{c}\text { Transmission loss } \\
\text { constrained by a given } \\
\text { cost }\end{array}$ & 90.00 & 4900.70 & 308822.30 \\
\cline { 2 - 4 } & & 4947.58 & 352970.20 \\
\hline
\end{tabular}

ment. In all situations, the criterion is to minimize the payback period. The computation of payback period is given by the following equation [1]:

$$
\text { Payback period }=\frac{\text { TCOST }}{\mathrm{UAB}}
$$

where

TCOST total cost of the compensator;

UAB uniform annual benefit.

\section{POWER FACTOR CORRECTION PROJECT ECONOMICS}

Total electricity costs for the energy customers consist of three parts: demand charges, energy charges, and $P F$ penalties. The contracted power was $P_{O} \mathrm{~kW}$ at $P F_{O}$. Therefore, the demand charges were $\left(87.6 \times \mathrm{P}_{\mathrm{O}}\right)$ L.E. according to the Egyptian tariff. The power is $P_{n} \mathrm{~kW}$ at $P F_{n}$ after correction. Therefore, the demand charges are $\left(87.6 \times \mathrm{P}_{\mathrm{n}}\right)$ L.E. By reducing contracted demand from $P_{O}$ to $P_{n}$, demand charges were reduced by $\left[87.6 \times\left(\mathrm{P}_{\mathrm{O}}-\mathrm{P}_{\mathrm{n}}\right)\right]$ L.E. Excluding the possible reduction in contract demand, the total annual savings resulting from the project $\left(\mathrm{S}_{\mathrm{e}}\right)$ are

$$
\begin{aligned}
\mathrm{S}_{\mathrm{e}}= & (\text { old } \mathrm{kWh} \text { charges }- \text { new } \mathrm{kWh} \text { charges }) \\
& +\left(0.9-\mathrm{PF}_{\mathrm{O}}\right) * \text { old } \mathrm{kWh} \text { charges } \\
& +\frac{\mathrm{PF}-0.92}{2} * \text { new } \mathrm{kWh} \text { charges L.E. }
\end{aligned}
$$

Including the contract demand reduction, the savings $\left(\mathrm{S}_{\mathrm{i}}\right)$ are as (7) with the term $\left[87.6 *\left(\mathrm{P}_{\mathrm{O}}-\mathrm{P}_{\mathrm{n}}\right)\right]$ is added. Note that the last term, in (7) is used if $\mathrm{PF}_{\mathrm{n}}>0.92$. The total investment required for this project is given by the following equation:

$$
\mathrm{TCOST}=\mathrm{U}_{\mathrm{C}} \mathrm{S}_{\mathrm{C}}+\mathrm{U}_{\mathrm{L}} \mathrm{S}_{\mathrm{L}}
$$

where $\mathrm{U}_{\mathrm{C}}$ and $\mathrm{U}_{\mathrm{L}}$ are, respectively, the costs of the capacitor and inductor per kilovolt ampere and considered to be constant parameters (60 L.E./kVA). $\mathrm{S}_{\mathrm{C}}$ and $\mathrm{S}_{\mathrm{L}}$ are, respectively, the volt-amperes ratings of the capacitor and inductor. If the total investment required for this project, using (8), the expected simple payback period for the project is $\left(\right.$ TCOST/ $\left.\mathrm{S}_{\mathrm{i}}\right)$ years including contract demand reduction. Excluding reduction gives a simple payback period of $\left(\mathrm{TCOST} / \mathrm{S}_{\mathrm{e}}\right)$ years.
TABLE II

PRoJeCt ECONOMICS OF CASE STUdY

\begin{tabular}{c|c|c}
\hline \multirow{2}{*}{$\mathrm{PF}_{\mathrm{n}}(\%)$} & \multicolumn{2}{|c}{ Payback period (years) } \\
\cline { 2 - 3 } & $\begin{array}{c}\text { Including reduction } \\
\text { in contract demand }\end{array}$ & $\begin{array}{c}\text { Excluding reduction } \\
\text { in contract demand }\end{array}$ \\
\hline 89.47 & 0.1459 & 0.1464 \\
\hline 89.77 & 0.1690 & 0.1693 \\
\hline 90.00 & 0.1139 & 0.1147 \\
\hline 95.00 & 0.1287 & 0.1293 \\
\hline
\end{tabular}

\section{CASE StUdy}

Consider the system under study [2] as: A three-phase load of $5100 \mathrm{~kW}$, and $4965 \mathrm{kVAR}$ is connected to a supply bus with voltage $4160-\mathrm{V}$ (2400 line-to-ground), $60-\mathrm{Hz}$ frequency and 80-MVA short circuit capacity. The contracted power is $5100 \mathrm{~kW}$ at $0.5464 \mathrm{PF}$. According to Egyptian tariff, the annual cost per kilowatt is currently L.E. 87.6. The consumption charge is 0.1535 L.E. $/ \mathrm{kWh}$. The simulated results using the suggested methods in [3] and [4] are given in Table I.

Using Section III to perform the project economics, the results are given in Table II.

\section{CONCLUSIONS}

Improving power factor resulted in reduction in all three electricity cost components. By reducing contract demand, demand charges were reduced. Because of the improvement in power factor, the maximum kilovolt amperes will decrease; this will reduce the internal losses and, in turn, the energy consumption. There are four alternatives for the compensator used: (a) Compensator for minimum transmission loss provided that it is greater than or equal 90\%; (b) compensator for maximum transmission efficiency provided that it is greater than or equal $90 \%$; (c) compensator for maximum $P F$ provided that it is greater than or equal $90 \%$ and less than or equal $95 \%$; (d) compensator for minimum transmission loss constrained by a given cost. A simple engineering economic analysis using simple payback period shows that the compensator, which yields most economical $P F$, is not necessarily equal with the compensator, which gives minimum transmission loss.

\section{REFERENCES}

[1] D. G. Newman, Engineering Economic Analysis. San Jose, CA 103: Engineering Press, 1980.

[2] IEEE Recommended Practices and Requirements for Harmonic Control in Electrical Power Systems, 1992.

[3] M. M. Abdel-Aziz, E. E. Abou El-Zahab, A. M. Ibrahim, and A. F. Zobaa, "Practical considerations on power factor correction for nonlinear loads," in Proc. IEEE Int. Conf. Harmon. Quality Power, Rio de Janeiro, Brazil, Oct. 6-9, 2002.

[4] M. M. Abdel-Aziz, E. E. Abou El-Zahab, and A. F. Zobaa, "LC compensators based on cost minimization for nonlinear loads," in Proc. Large Eng. Syst. Conf. Power Eng., Montreal, QC, Canada, May 7-9, 2003, pp. 143-147. 